\title{
OBTAINING AND APPLICATION OF NEW CELLULOSE- AND GRAPHENE OXIDE-BASED ADSORBENTS FOR TREATMENT OF INDUSTRIAL WASTE CONTAINING HEAVY METALS
}

\author{
Beata Fryczkowska', Mirosław Wyszomirski², Monika Puzoń \\ 1 Faculty of Materials, Civil and Environmental Engineering, Institute of Textile Engineering and Polymer \\ Materials, University of Bielsko-Biala, Willowa 2, 43-309 Bielsko-Biala, Poland \\ Corresponding author's e-mail: bfryczkowska@ath.bielsko.pl
}

Received: 2017.04.30

Accepted: 2017.07.05 Published: 2017.11.01

\begin{abstract}
The paper presents the results of studies on the preparation and properties of composite granules produced by phase inversion from cellulose (CEL) solutions in 1-ethyl3-methylimidazole acetate (EMIMAc), containing nano-addition in the form of graphene oxide (GO) in N,N-dimethylformamide (DMF). Water absorption and sorption of such compounds as $\mathrm{FeCl}_{3}$, methylene blue (MB) and bovine serum albumin (BSA) were studied. In addition, attempts were made to investigate the sorption properties of the obtained cellulose granules in terms of metals removal from galvanizing wastewater. Among the many components, iron and lead were found to have the highest concentration $\left(\sim 1 \mathrm{mg} \mathrm{Fe} / \mathrm{dm}^{3} ; \sim 2 \mathrm{mg} \mathrm{Pb} / \mathrm{dm}^{3}\right)$ in the tested wastewater sample. The qualitative and quantitative composition of the wastewater was examined by UV-Vis spectrophotometry. The studies show that doping of cellulose with graphene oxide clearly affects the physical properties of this biopolymer. GO improves the water absorption of CEL/GO composite cellulose granules only in the concentration above $0.05 \% \mathrm{w} / \mathrm{w}$. For a concentration of $0.1 \% \mathrm{w} / \mathrm{w}$ of GO in cellulose, water absorption is increased by $\sim 108 \%$ compared to pure cellulose granules. In addition, the use of dry and wet granules in the study changes their sorption properties with respect to all tested substances. Studies on test solutions have shown that the sorption of cellulose granules decreases with increasing molar mass of test compounds, in the following order: $\mathrm{FeCl}_{3}$, methylene blue (MB) and bovine albumin (BSA). This means that the cellulose granules obtained in the experiment are made up of small micropores, which makes the diffusion of compounds of high molecular weight difficult. The best sorption results were obtained for ferric ions and amounted to $66-72 \%$ for $\mathrm{FeCl}_{3}$ solution, and $\sim 92 \%$ for the wastewater that was sorbed on pure cellulose granules.
\end{abstract}

Keywords: cellulose, graphene oxide, sorption, galvanizing wastewater

\section{INTRODUCTION}

Cellulose is one of the most abundant naturally occurring polymers that, thanks to its popularity and low price, is used in both unprocessed form and as derivatives. The chemical structure of the cellulose molecule directly affects its properties, particularly the poor solubility of this biopolymer in conventional organic solvents, which limits its processing. An interesting alternative in cellulose processing are room-temperature ionic liquids (RTILs), which due to their low toxicity and degradability are called "green" solvents [Gathergood et al. 2004, Earle et al. 2000, Novoselov et al. 2007]. Ionic liquids were discovered in 1960 , and interest in them increased sharply in the early 21 st century. The most interesting are the features of room-temperature ionic liquids (RTILs), which are liquid at room temperature [Laus et al. 2005]. Ionic fluids are used to dissolve, in mild condi- 
tions, very sparingly soluble materials such as cellulose [Fukaya 2008]. Therefore, they are called direct cellulose solvents. Swatloski et al. [2002] were first to describe the dissolution of cellulose in 1-butyl-3-methyl imidazolium chloride. The cellulose dissolved in ionic liquids can be easily precipitated using polar solvents (water, ethyl alcohol, acetone, methylene chloride, acetonitrile) to obtain flocs, fibres or membranes [Pinkert et al. 2009, Zhu et al. 2006]. The regenerated cellulose thus obtained is less crystalline and more porous than native cellulose.

An interesting and modern material, which is a source of great hopes among scientists around the world, is graphene and graphene oxide. An important feature of graphene oxide is the hydrophilic properties resulting from its chemical structure. Thanks to this, graphene oxide has excellent metal ions sorption properties for such metals as $\mathrm{Co}(\mathrm{II}), \mathrm{Cu}(\mathrm{II}), \mathrm{Zn}(\mathrm{II}), \mathrm{Cd}(\mathrm{II}), \mathrm{Ni}, \mathrm{As}(\mathrm{III}), \mathrm{As}(\mathrm{V})$, $\mathrm{Pb}(\mathrm{II}), \mathrm{Au}(\mathrm{III}), \mathrm{Eu}(\mathrm{III})$ and $\mathrm{U}(\mathrm{VI})$ [Sitko et al. 2013]. Apart from the sorption properties, graphene oxide has many other features that Fryczkowski et al. [2013] are using to obtain polymer composites with special properties.

Heavy metals are present in industrial wastewater and they are removed by various methods. The simplest method is to precipitate them in the form of sparingly soluble compounds (hydroxides, sulphides, sulphates and carbonates) [Grabas 2009, Bartkiewicz et al. 2010]. Metallic contaminants can be removed using mineral coagulants [Łomonowski 2007] or natural (starch, gelatine) and synthetic (e.g. polyacrylamides, polyvinyl alcohol and other) flocculants [Łomotowski et al. 2002]. Another method of purifying water from heavy metals is the use of very efficient and effective ion exchange methods using inorganic [Anielak 1998] and organic [Bożęcka et al. 2016] ion-exchanger materials. Sorption methods are another way to remove and recover metals from water and sewage. Lach et al. [2011] used activated carbons as sorbents. Harmful substances can also be adsorbed using natural sorbents. An interesting example is the use of sunflower silique to remove bivalent ions, with good process efficiency [Bożęcka et al. 2016]. Rajczykowski and Loska [2016] investigated the adsorption of cadmium on straw. The desirable feature of sorbents is their biological inertness and degradation to non-toxic substances. Examples of substances that meet the above requirements are biopolymers, including cellulose and its derivatives, e.g. chitosan [Struszczyk 2002, Piątkowski et al. 2011, Radomski et al. 2014]. Literature reports the method of obtaining cellulose granules which Suzuki et al. [2016] obtained from microcrystalline cellulose dissolved in 1-butyl-3-methylimidazolium chloride. With the same ingredients Yei et al. [2016] formed cellulose composites, which additionally contained graphene.

In the paper, the study of combining the commonly used biopolymer that is cellulose (CEL) with graphene oxide (GO) to obtain a CEL/GO composite material with sorption properties. Cellulose was dissolved in a direct solvent that was 1-ethyl-3-methylimidazole acetate (EMIMAc) resulting in a 5\% solution. The graphene oxide obtained in the experiment, on the other hand, was dispersed in N,N-dimethylformamide (DMF) to obtain a $3.7 \% \mathrm{GO} / \mathrm{DMF}$ dispersion. The resulting solutions were combined and then droplets were formed and coagulated in distilled water. The purpose of the study was to determine the water absorption and sorption properties of the produced CEL/GO composite granules in relation to selected chemicals and wastewater containing metals.

\section{MATERIALS AND TEST METHODS}

\section{Reagents}

Long-fibre cellulose (CEL) purchased from Sigma Life Science. 1-ethyl-3-methylimidazole acetate (EMIMAc) $(90 \%)$, bovine serum albu$\min (\mathrm{BSA})\left(\mathrm{M}_{\mathrm{w}}=\sim 66 \mathrm{kDa}\right)$, graphite powder $<20$ $\mu \mathrm{m}$, methylene blue (MB), anhydrous $\mathrm{FeCl}_{3}$ purchased from Sigma-Aldrich. N,N-dimethylformamide (DMF), $\mathrm{NaNO}_{3}, 98 \% \mathrm{H}_{2} \mathrm{SO}_{4}, \mathrm{KMnO}_{4}$, $30 \% \mathrm{H}_{2} \mathrm{O}_{2}$ purchased from Avantor Performance Materials Poland S.A.

\section{Synthesis of graphene oxide and graphene}

Graphene oxide was obtained according to modified Hummers method [1958]. The process to obtain GO was already described in our previous paper [Fryczkowska et al. 2015]. The resulting GO powder was dispersed in DMF using an ultrasonic bath. As a result of the experiment, $3.7 \% \mathrm{GO} / \mathrm{DMF}$ mixture was obtained. 


\section{Forming CEL/GO granules}

A $5 \%$ solution of the long-fibre cellulose (CEL) in the ionic liquid - 1-ethyl-3-methylimidazole acetate (EMIMAc) - was prepared. Appropriate amounts of cellulose and ionic liquid were weighed, everything was mixed well and then heated in a microwave oven until clear solution was obtained. The solution was allowed to deaerate for 24 hours. Appropriate amounts of $3.7 \% \mathrm{w} / \mathrm{w}$ of $\mathrm{GO}$ dispersion in dimethylformamide (GO/DMF) were added to thus prepared cellulose solution (Tab. 1), then stirred and sonicated for 30 minutes in an ultrasonic bath.

Cellulose granules were formed using a syringe. To this end, the drops of $\mathrm{CEL} / \mathrm{GO} /$ EMIMAC solution were extruded from the syringe and into a beaker with distilled water. Under the influence of water the elution of the ionic liquid and coagulation of cellulose doped with graphene oxide occurred. The resulting granules were left in distilled water for 1 week and then filtered and dried. Drying took place for 24 hours at room temperature, followed by another 24 hours of drying in a laboratory oven at $50{ }^{\circ} \mathrm{C}$.

\section{Study of water absorption}

The water absorption study of cellulose granules was carried out in such a way that 5 pieces of granules were added to the glass vials that were weighed accurately on the analytical balance. Then, $5 \mathrm{~cm}^{3}$ of distilled water was added to each vial. Vials were tightly capped and left for 24 hours. After this time, the granules were filtered off gently with a filter paper to remove water and re-weighed. The water absorption (W) was calculated from the formula (1). The results are presented in Figure 1.

$$
W=\left(\frac{m_{1}-m_{2}}{m_{1}}\right) \times 100 \%
$$

where: $m_{2}$ - mass of wet granules;

$m_{l}-$ weigh of dry granules

\section{Study of the sorption properties}

The sorption properties of cellulose granules were determined using molecules that varied considerably in size, from which standard solutions of the following concentrations were obtained:

Table 1. Composition of solution to form CEL/GO granules

\begin{tabular}{|c|c|c|c|}
\hline Designation of CEL/GO granules & Amount of cellulose [g] & Amount of GO/DMF [g] & Amount of EMIMAC [g] \\
\hline „0" & 2.5 & 0 & 47.5 \\
\hline A & 2.5 & 0.135 & 46.2 \\
\hline B & 2.5 & 0.34 & 46.8 \\
\hline C & 2.5 & 0.67 & 47.2 \\
\hline D & 2.5 & 1.35 & 47.4 \\
\hline
\end{tabular}

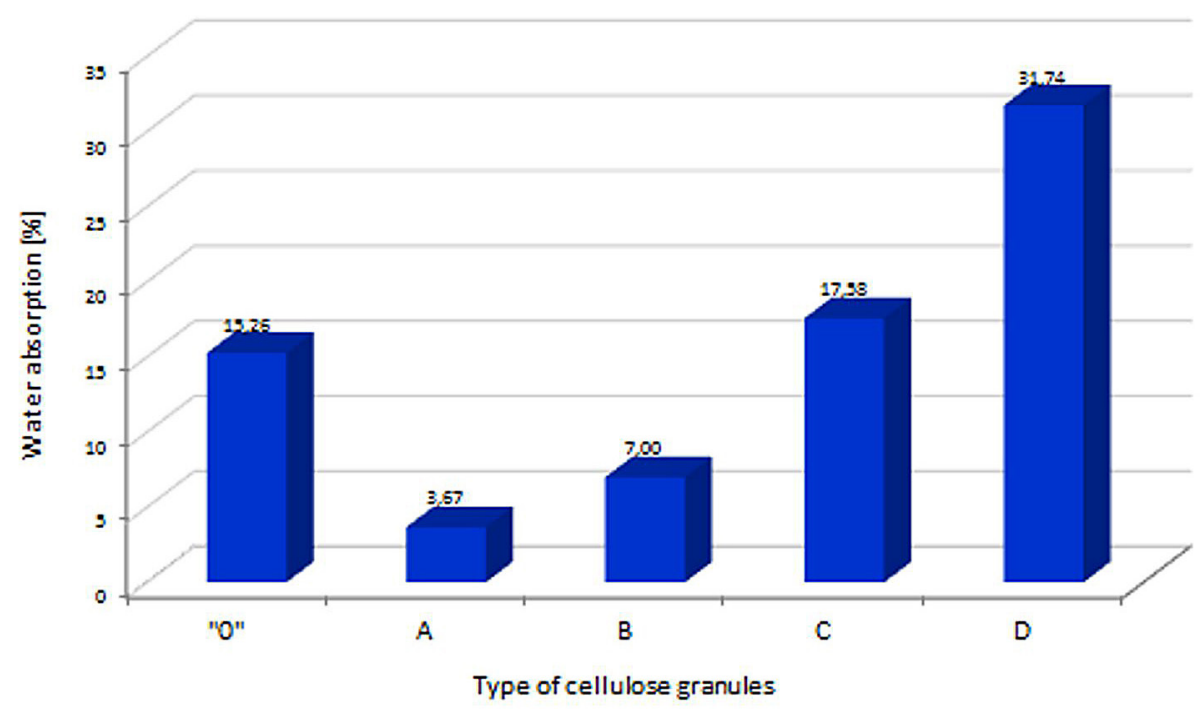

Fig. 1. Results of water absorption of cellulose granules of pure cellulose and CEL/GO composites 
$0.1 \mathrm{~g} / \mathrm{dm}^{3} \mathrm{FeCl}_{3}\left(\mathrm{M}_{\mathrm{w}}=162.20 \mathrm{~g} / \mathrm{mol}\right), 0.0001$ $\mathrm{mol} / \mathrm{dm}^{3} \mathrm{MB}\left(\mathrm{M}_{\mathrm{w}}=319.85 \mathrm{~g} / \mathrm{mol}\right)$ and $1.0 \mathrm{~g} /$ $\mathrm{dm}^{3}$ BSA $\left(\mathrm{M}_{\mathrm{w}}=\sim 60 \mathrm{kDa}\right)$. In addition, the sorption properties of the granules were investigated on the basis of the procedure developed previously [Fryczkowska et al. 2017] for galvanizing wastewater (Tale 2).

Two series of samples of cellulose granules were prepared. One series were dry granules. The second series were wet granules - immersed for 24 hours in distilled water and drained thoroughly. To each of the glass vials 5 cellulose granules, weighed on an analytical balance, were placed, and then $5 \mathrm{~cm}^{3}$ of successive solutions and wastewater were added. Vials were tightly capped and left for 24 hours.

The concentration of the solutions from above the granules was then tested. The concentrations of the standard solutions were tested using Perkin Elmer Lambda 35 UV-Vis spectrophotometer: $\mathrm{FeCl}_{3}(\lambda=260 \mathrm{~nm}), \mathrm{MB}(\lambda=662$ $\mathrm{nm})$ and $\operatorname{BSA}(\lambda=280 \mathrm{~nm})$. Iron in wastewater was determined using ready Hach cuvette test sets with $\mathrm{HACH}$ spectrophotometer model DR4000. Lead was determined by conductometric method, according to the methodology developed by Minczewski and Marczenko [2007]. The reaction and conductivity of the solution was tested using Elmetron CPC 511 laboratory $\mathrm{pH} /$ conductivity meter. The results are summarized in Table 3.
Formula (2) allowed to calculate the degree of removal (R) of successive substances from the tested solutions [Akbari 2016]. The calculation results are shown in Fig. 2-5.

$$
R=\left(\frac{C 1-C_{2}}{C_{1}}\right) \times 100 \%
$$

where: $C_{2}-$ concentration of the component in the solution after test; $C_{1}$ - concentration of the component in the solution before testing

\section{Surface morphology}

Observations of the granules surface morphology and their cross sections were carried out using JSM - 5500 LV JEOL scanning electron microscope (SEM). All samples were coated with a layer of gold in JEOL JFC 1200 vacuum coater at $3 \times 10-5 \mathrm{Tr}$.

\section{RESULTS AND ANALYSIS}

Water absorption test results (Fig. 1) have shown that cellulose granules "0" absorb about $15 \%$ of water relative to their mass. On the other hand, in the case of composite granules, it was observed that small additions of graphene oxide (A and B) cause a decrease in water absorption, which may be due to the presence of GO on the

Table 2. Selected physical and chemical properties of the waste water

\begin{tabular}{|c|c|c|c|c|c|c|}
\hline Designation & $\mathrm{pH}$ & Conductivity $[\mu \mathrm{S} / \mathrm{cm}]$ & $\mathrm{Fe}\left[\mathrm{mg} / \mathrm{dm}^{3}\right]$ & $\mathrm{Zn}\left[\mathrm{mg} / \mathrm{dm}^{3}\right]$ & $\mathrm{Cd}\left[\mathrm{mg} / \mathrm{dm}^{3}\right]$ & $\mathrm{Pb}\left[\mathrm{mg} / \mathrm{dm}^{3}\right]$ \\
\hline Numeric value & 6.90 & 1400 & 1.02 & 0.61 & 0.06 & 2.06 \\
\hline
\end{tabular}

Table 3. Results of studies of selected physicochemical properties of wastewater after sorption on pure cellulose granules and CEL/GO composite granules

\begin{tabular}{|c|c|c|c|c|c|c|c|c|c|c|c|}
\hline \multirow{2}{*}{ Parameter } & \multirow{2}{*}{$\begin{array}{l}\text { Initial } \\
\text { values }\end{array}$} & \multicolumn{2}{|c|}{ Granules "0" } & \multicolumn{2}{|c|}{ Granules A } & \multicolumn{2}{|c|}{ Granules B } & \multicolumn{2}{|c|}{ Granules C } & \multicolumn{2}{|c|}{ Granules D } \\
\hline & & dry & wet & dry & wet & dry & wet & dry & wet & dry & wet \\
\hline $\mathrm{pH}$ & 6.90 & 6.82 & 7.20 & 6.92 & 7.30 & 6.92 & 7.15 & 7.10 & 6.89 & 6.95 & 6.85 \\
\hline $\begin{array}{l}\text { Conductivity } \\
{[\mu S / \mathrm{cm}]}\end{array}$ & 1400 & 1910 & 1400 & 1840 & 1380 & 1880 & 1390 & 1810 & 1380 & 1850 & 1410 \\
\hline $\mathrm{FeCl}_{3}\left[\mathrm{~g} / \mathrm{dm}^{3}\right]$ & 0.1 & 0.030 & 0.030 & 0.029 & 0.033 & 0.028 & 0.033 & 0.031 & 0.033 & 0.033 & 0.034 \\
\hline $\mathrm{MB}\left[\mathrm{mol} / \mathrm{dm}^{3}\right]$ & 0.0001 & $9.2 \mathrm{E}-05$ & 8.3E-05 & 8.0E-05 & 8.2E-05 & 8.4E-05 & 8.1E-05 & 7.5E-05 & 7.5E-05 & 7.3E-05 & 6.3E-05 \\
\hline $\mathrm{BSA}\left[\mathrm{g} / \mathrm{dm}^{3}\right]$ & 1.0 & 1.0 & 1.0 & 1.0 & 1.0 & 1.0 & 1.0 & 1.0 & 1.0 & 1.0 & 1.0 \\
\hline $\mathrm{Fe}\left[\mathrm{mg} / \mathrm{dm}^{3}\right]$ & 1.02 & 0.08 & 0.45 & 0.72 & 0.63 & 0.21 & 0.32 & 0.31 & 0.63 & 0.48 & 0.63 \\
\hline $\mathrm{Pb}\left[\mathrm{mg} / \mathrm{dm}^{3}\right]$ & 2.06 & 1.34 & 1.55 & 1.34 & 1,65 & 1.45 & 1.75 & 1.45 & 1.86 & 1.55 & 1.86 \\
\hline
\end{tabular}

* Research done on AAS.

** Results of research in a publication prepared for printing [Turek et al.]. 
surface of the granules, which hydrophobises the cellulose surface. For granules D containing 0.1 $\% \mathrm{w} / \mathrm{w}$ of GO, water absorption doubles, compared to pure cellulose. The results indicate that the minimum amount of graphene oxide addition is $0.05 \% \mathrm{w} / \mathrm{w}$, since above this concentration GO is dispersed throughout the volume of the granules, not just on their surface.

Studying the sorption of $\mathrm{FeCl}_{3}$ solution on cellulose granules (Fig. 2) it can be observed that dry samples adsorb the solution better than wet samples. The " 0 " granules, obtained from pure cellulose, sorb $\sim 70 \%$ of iron from the test sample. For dry composite granules, a slight increase of the $\mathrm{FeCl} 3$ solution sorption is observed, followed by a sorption decrease, the difference being small and within the range of $\pm 1 \div 3 \%$. In contrast, iron (III) chloride sorption decreases for wet granules in order from " 0 " to D. The results of the tests show that the removal of iron from the solution is high $(66 \div 72 \%)$. Furthermore, there is no significant increase in the sorption properties expected for cellulose granules with graphene oxide addition. It is also worth noting that compared to the values of water absorption (Fig. 1) the presence of iron ions improves the sorption properties of all the obtained granules.

Sorption studies conducted on a dye (Fig. 3) allow to observe that the methylene blue molecule is poorly adsorbed on cellulose granules. The "0" granules are characterized by the worst sorption properties which for dry samples are $\sim 8 \%$, while for wet ones $\sim 17 \%$. GO addition slightly improves the sorption of the dye, which for the composite granules is $\sim 17 \pm 19 \%$ (granules A), $\sim 18 \pm 20 \%$ (granules B), $\sim 25 \%$ (granules C), $\sim 27$ granules D (dry) and $\sim 37 \%$ granules D (wet). In the case of sorption studies with the use of $\mathrm{MB}$, it is observed that with increasing concentration of $\mathrm{GO}$ addition, the adsorption of dye on cellulose granules increases. Low sorption values may be related to the way in which cellulose granules are formed, resulting in the occurrence on their surface of micropores the diameter of which dampens the dye diffusion into the interior of the granule.

BSA sorption studies by cellulose granules (Fig. 4) showed that dry granules did not adsorb proteins at all, whereas sorption of wet granules was very low and ranged between 3.6 and $6.7 \%$. These results may confirm that the protein molecules are too large to diffuse into the granules, as also seen in Figure 3. In addition, large protein particles are negatively charged, which can promote electrostatic interaction with cellulose chains and "screen" access and diffusion of water into the granules, resulting in no sorption for the dry granules. The wet granules, on the other hand, are slightly swollen, which may have improved the BSA adsorption on their surface. The result of this behaviour are very low values of protein adsorption on pure cellulose granules $(\sim 6.7 \%)$ and even lower sorption values for other CEL/GO granules. Observing the changes in the adsorption of composite granules, it can be seen that it is growing in the direction from the lowest to the highest GO concentration, similar to Figure 3 discussed earlier.

Studies of iron sorption from wastewater showed that, similarly as in Figure 2, dry cellulose

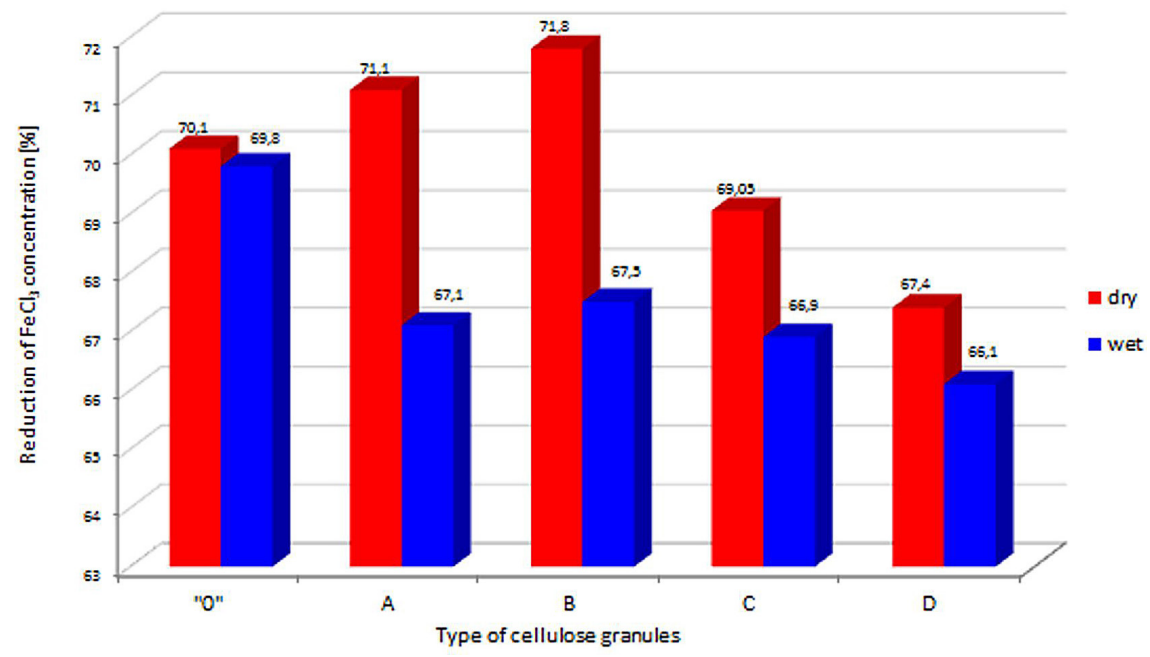

Fig. 2. A drop in $\mathrm{FeCl}_{3}$ concentration as a result of sorption on pure cellulose granules and $\mathrm{CEL} / \mathrm{GO}$ composite granules 


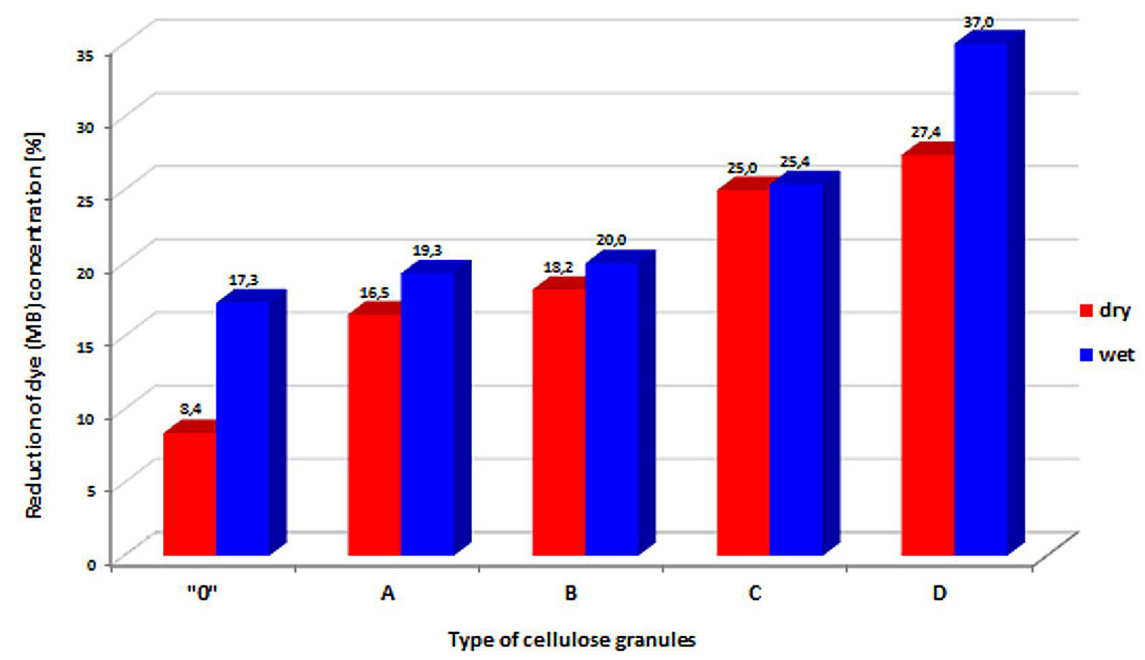

Fig. 3. A drop in methylene blue (MB) concentration as a result of sorption on pure cellulose granules and $\mathrm{CEL} / \mathrm{GO}$ composite granules

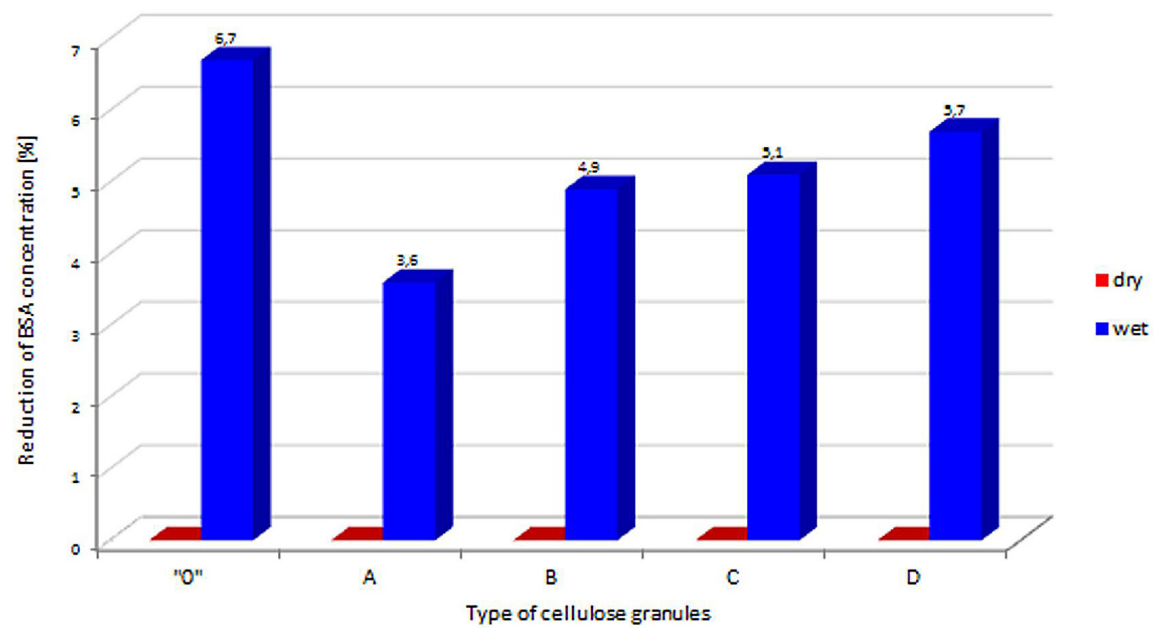

Fig. 4. A drop in BSA concentration as a result of sorption on pure cellulose granules and $\mathrm{CEL} / \mathrm{GO}$ composite granules

granules adsorb iron ions better than wet ones. The absorption of iron on dry cellulose granules " 0 " is the highest $(\sim 92 \%)$ relative to the others. By contrast, wet granules obtained from pure cellulose remove $\sim 56 \%$ of iron from wastewater. In the electroplating wastewater environment CEL/ GO granules behave differently than in a solution containing only $\mathrm{Fe}^{3+}$ ions (Fig. 2). It is observed that granules $\mathrm{A}$ are characterized by the worst sorption of iron from wastewater $(30 \div 39 \%)$, only the higher $\mathrm{GO}$ addition $(0.025 \%$ of $\mathrm{GO} / \mathrm{CEL})$ facilitates its removal. In the case of granules B, C, $\mathrm{D}$ the iron sorption decreases, similarly as for the standard $\mathrm{FeCl}_{3}$ solution (Fig. 2). There are also larger differences in sorption values between dry and wet granules of $\sim 26 \%$ (granules " 0 "), $\sim 7 \%$ (granules A), $\sim 10 \%$ (granules B), $\sim 21 \%$ (granules
C), $\sim 4 \%$ (granules D), respectively. These results differ from the ones obtained with the standard solution of $\mathrm{FeCl}_{3}$, which confirms that the complex composition of the wastewater and the reactions in it affect the sorption properties of the sorbent used.

Figure 6 presents the decrease in lead concentration in the studies wastewater. The analysis showed that lead is more difficult to remove from wastewater than iron (Fig. 5). It is observed that lead sorption is the highest for pure cellulose pellets " 0 ", then the values fall for the CEL/GO composite granules, with an increase in the concentration of the addition (GO). Pure cellulose granules: $\sim 35 \%$ dry granules and $\sim 25 \%$ wet granules are characterized by the best sorption properties for lead. Studies on the removal of lead have shown that the sorption 


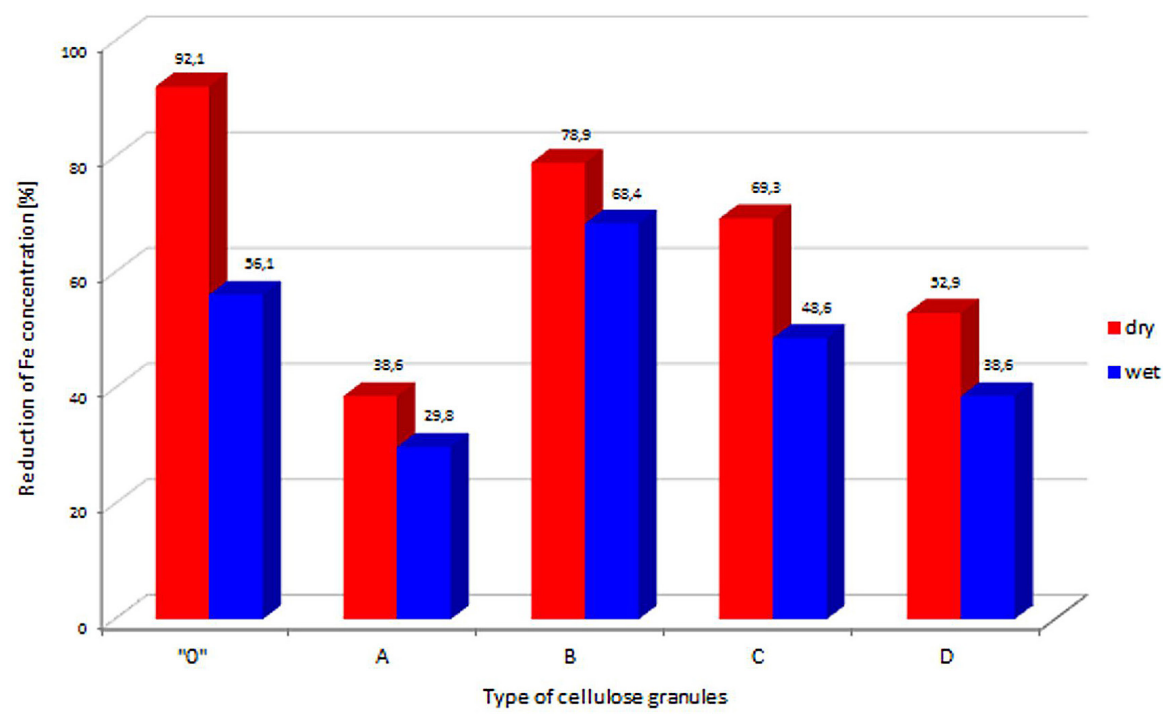

Fig. 5. A drop in iron concentration in wastewater as a result of sorption on pure cellulose granules and CEL/GO composite granules

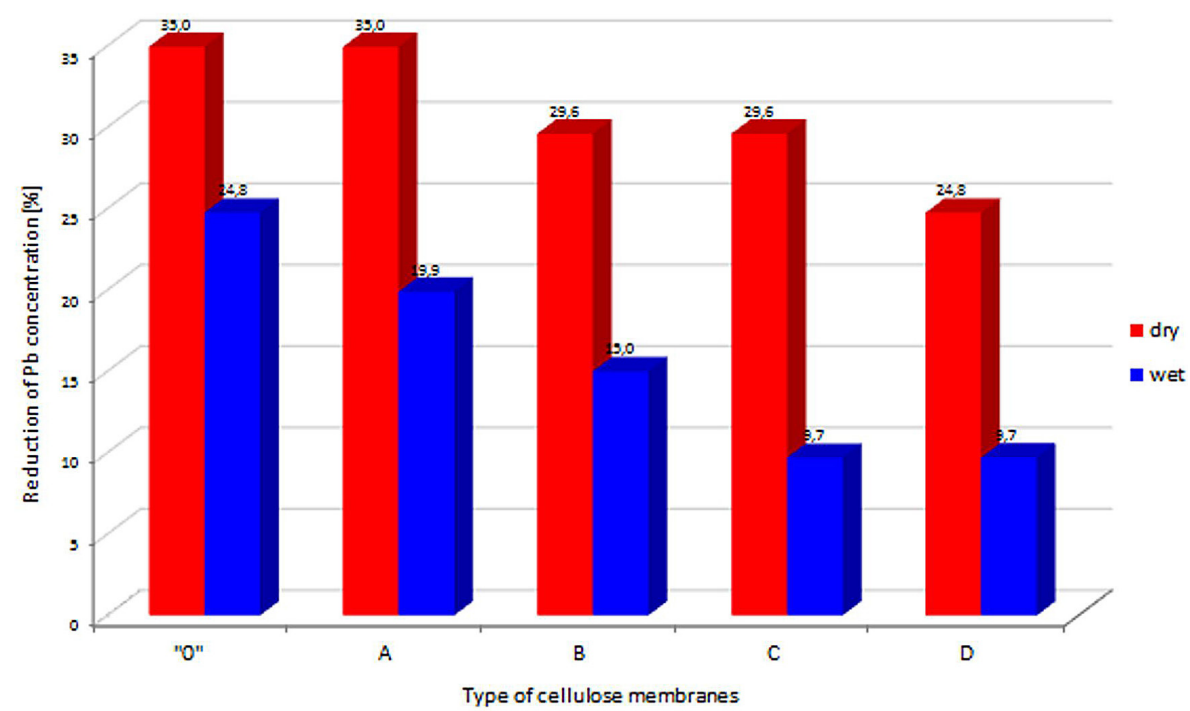

Fig. 6. A drop in lead concentration in wastewater as a result of sorption on pure cellulose granules and CEL/GO composite granules

of the metal is higher for the dried granules $(25 \div 35 \%)$, while the adsorption of this metal on the wet cellulose granules is lower and takes values between 10 and $25 \%$.

Scanning microscopy (Fig. 7) allowed to observe the surface morphology of cellulose granules. Pure cellulose pellets (" 0 ") have holes on their surface, which can facilitate the diffusion of water into their interior. In the case of composite granules $\mathrm{D}$, it is observed that the morphology of the granules surface is more complicated, and the photographs show ripples and roughness. Such surface structure is conductive to high water sorption properties, compared to other CEL/GO composite granules, which is confirmed by the test results (Fig. 1.).

The $\mathrm{pH}$ and conductivity studies (Table 3 ) in the wastewater confirm that the qualitative and quantitative composition of the electroplating wastewater is changing during the sorption on " 0 " pure cellulose granules and CEL/GO composite granules. The results are changes of $\mathrm{pH}$ values that range between $6.82 \div 7.1$ (for dry granules) and $6.85 \div 7.3$ (for wet granules). Higher diversity is observed for the measurements of conductivity that slightly decreases during testing of wet granules and is significantly increased by $30 \div 36 \%$ for dry granules. The increase in conductivity of the 
a)

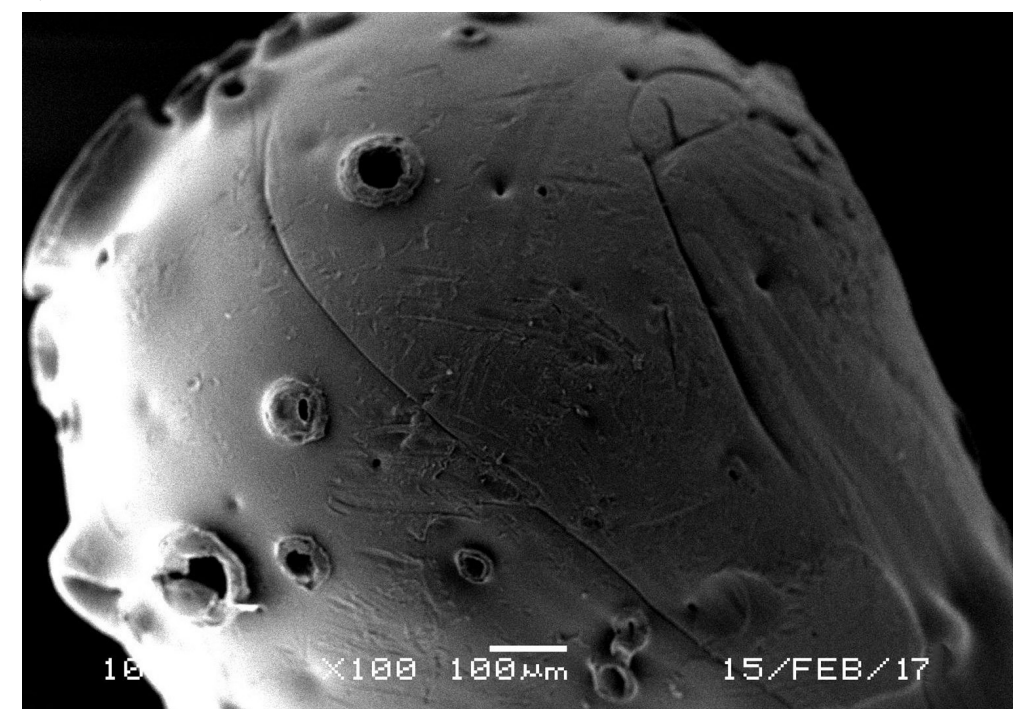

b)

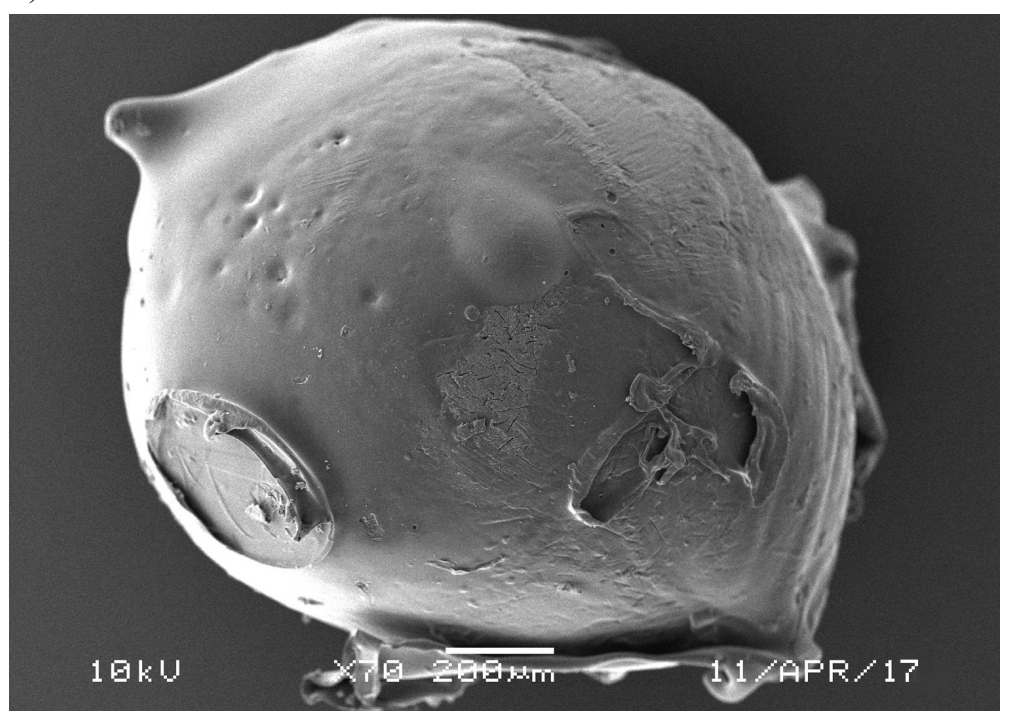

c)

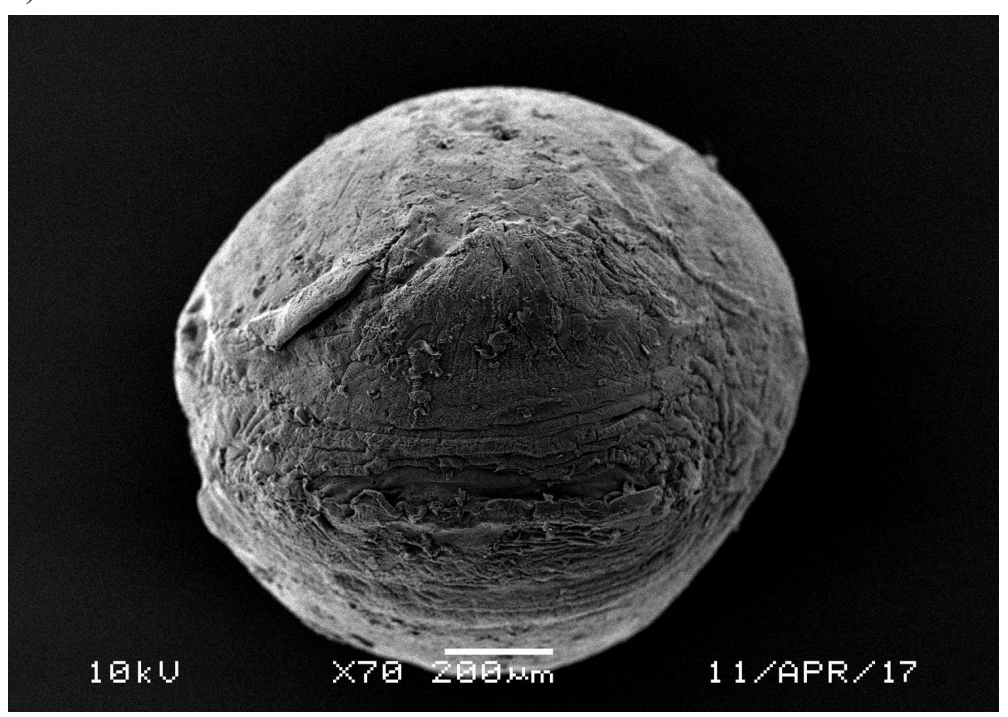

Fig. 7. SEM photos of granules: a) granule "0"; b) composite granule A; c) composite granule D 
tested solutions may be influenced by the presence of an ionic liquid (EMIMAc) that may have been inaccurately removed during the filtration of the granules in their forming phase.

\section{CONCLUSIONS}

The paper proposes a method of obtaining sorbents that can be used to remove metals from wastewater. Sorbents were obtained by combining a biopolymer that is cellulose with graphene oxide, which is used for sorption of heavy metals. As a result of the experiment, composite cellulose granules were obtained, differing in physicochemical properties and surface morphology, which directly affect water absorption and sorption properties. The studies have shown that drying cellulose granules in the process of their production $\left(\right.$ at $50{ }^{\circ} \mathrm{C}$ ) results in a low water absorption of about $4 \div 32 \%$. The sorption properties of the obtained granules are $66 \div 72 \%$ for $\mathrm{FeCl}_{3}$, $8 \div 37 \%$ for methylene blue (MB), $0 \div 7 \%$ for BSA, respectively. The studies have also shown that pure cellulose granules (granules " 0 ") adsorb about $92 \%$ of iron and $35 \%$ of lead from wastewater. And CEL/GO composite granules are characterized by 30 to $79 \%$ iron sorption and 10 to $35 \%$ lead sorption from the waste water, depending on the amount of GO addition.

These studies enable to obtain sorbent that can effectively remove iron from electroplating wastewater. The advantage of cellulose granules and graphene doped granules is their full biodegradability and possibility of energy recycling.

\section{Acknowledgements}

We would like to thank mgr inż. Marta Sieradz$\mathrm{ka} / \mathrm{MSc}$, Eng./ for synthesizing graphene oxide.

\section{REFERENCES}

1. Akbari A., Yegani R., Pourabbas B. 2016. Synthesis of high dispersible hydrophilic poly(ethylene glycol)/ vinyl silane grafted silica nanoparticles to fabricate protein repellent polyethylene nanocomposite. European Polymer Journal, 81, 86-97.

2. Anielak A. M. 1998. Chemical and physicochemical wastewater treatment (in Polish). Wydawnictwo Uczelniane Politechniki Koszalińskiej, 275-289.

3. Bartkiewicz B., Umiejewska K. 2010. Treatment of industrial wastewater (in Polish). Wydawnictwo
Naukowe PWN.

4. Bożęcka A., Orlof-Naturalna M., Sanak-Rydlewska S. 2016. The possibilities of using the ion exchange process of on sorbents for the purification of aqueous solutions from toxic metal ions. Zeszyty Naukowe Instytutu Gospodarki Surowcami Mineralnymi i Energii PAN, 94, 185-196.

5. Earle M.J., Seddon K.R. 2000. Ionic liquid : Green solvents for the future. Pure Applied Chemistry, 72, 1391-1398.

6. Fryczkowska B., Sieradzka M., Sarna E., Fryczkowski R., Janicki J. 2015. Influence of a graphene oxide additive and the conditions of membrane formation on the morphology and separative properties of poly(vinylidene fluoride) membranes. Journal of Applied Polymer Science, 132, 46.

7. Fryczkowski R., Gorczowska M., Ślusarczyk Cz., Fryczkowska B., Janicki J. 2013. The possibility of obtaining graphene/polymer composites from graphene oxide by a one step process. Composites Science and Technology, 80, 87-92.

8. Fukaya Y., Hayashi K., Wada M., Ohno H. 2008. Cellulose dissolution with polar ionic liquids under mild conditions: required factors for anions. Green Chemistry, 10(1), 44-46.

9. Gathergood N., García M. T., Scammells P. J. 2004. Biodegradable ionic liquids: Part I. Concept, preliminary targets and evaluation. Green Chemistry, 6, 166-175.

10. Grabas K., 2009. Removal of heavy metal ions from industrial effluents and super-slurry from "Kowary" pond (Jelenia Góra district) (in Polish). Ochrona Środowiska, 31(2), 49-54.

11. Greluk M., Hubicki Z. 2011. Acrylic anion exchangers modified by SPADNS as ionic chelators for thickening of metal ions (in Polish). Przemysł Chemiczny, 90(1), 104-111.

12. Hummers W. S. and Offeman R. E. 1958. Preparation of Graphitic Oxide. Journal of the American Chemical Society, 80(6), 1339-1339.

13. Lach J., Okoniewska E., Ociepa E. 2011. Influence of heavy metal ions on adsorption of $\mathrm{Cr}(\mathrm{VI})$ from aqueous solutions on g-12 and f-300 activated carbons (in Polish). Nauka Przyroda Technika, 5, 4.

14. Laus G., Bentivoglio G., Schottenberger H., Kahlenberg V., Kopacka H., Röder T., Sixta H. 2005. Ionic Liquids: Current Developments, Potential and Drawbacks for Industrial Applications. Lenzinger Berichte, 84,71-85.

15. Łomotowski J. 2007. Application of mineral coagulants in water and wastewater technology (in Polish). Forum eksploatatora, 3(30), 19-22.

16. Łomotowski J., Szpindor A. 2002. Modern wastewater treatment systems (in Polish). Arkady, Warszawa. 
17. Minczewski J. Marczenko Z. 2007. Analytical Chemistry vol. 2 (in Polish). Wydawnictwo Naukowe PWN.

18. Novoselov N.P., Sashina E.S., Kuz'mina O.G., Troshenkova S.V. 2007. Ionic Liquids and Their Use for the Dissolution of Natural Polymers. Russian Journal of General Chemistry, 77, 1395-1405

19. Piątkowski M., Bogdał D., Radomski P., Jarosiński A. 2011. Chitosan-based hydrogel for industrial waste treatment. Technical Transactions, 8, 127-134.

20. Pinkert A., Marsh K.N., Pang S., Staiger M.P. 2009. Ionic Liquids and Their Interaction with Cellulose. Chemical Reviews, 109, 6712-6728.

21. Radomski P., Piątkowski M., Bogdał D. 2014. Application of chitosan and its modified derivatives for removing of heavy metal ions from industrial wastes. Chemik, 68(1), 39.

22. Rajczykowski K., Loska K. 2016. Comparison of cadmium adsorption process on barley straw in batch and flow reactors. Dealination and Water Treatment, 57(3), 1-7.

23. Sitko R., Zawisza B., Malicka E. 2013. Graphene as a new sorbent in analytical chemistry. Trends in Analytical Chemistry, 51, 33-43.

24. Struszczyk M.H. 2002. Chitin and chitosan, part I. Properties and production. Polimery, 47(5), 316-323.

25. Suzuki T., Kono K., Shimomura K., Minami H. 2014. Preparation of cellulose particles using an ionic liquid. Journal of Colloid and Interface Science, 418, 126-131.

26. Swatloski R.P., Spear S.K., Holbrey J.D., Rogers R.D. 2002. Dissolution of cellulose with ionic liquids. Journal of the American Chemical Society, 124(18), 4974-4975.

27. Ye W., Li X., Zhu H., Wang X., Wang S., Wang H., Sun R. 2016. Green fabrication of cellulose/graphene in ionic liquid and its electrochemical and photothermal properties. Chemical Engineering journal, 299, 45-55.

28. Zhu S., Wu Y., Chen Q., Yu Z., Wang C., Jin S., Ding Y., Wu G. 2006. Dissolution of cellulose with ionic liquid sang its application: a mini-review. Green Chemistry, 8, 325-327. 